\title{
Iron Oxide and Titanium Dioxide Nanoparticle Effects on Plant Performance and Root Associated Microbes
}

\author{
David J. Burke ${ }^{1, *}$, Nicole Pietrasiak ${ }^{1}$, Shu F. Situ ${ }^{2}$, Eric C. Abenojar ${ }^{2}$, Mya Porche ${ }^{2}$, \\ Pawel Kraj ${ }^{2,3}$, Yutthana Lakliang ${ }^{2}$ and Anna Cristina S. Samia ${ }^{2, *}$
}

1 Holden Arboretum, Kirtland, OH 44094, USA; E-Mail: npietrasiak@jcu.edu

2 Department of Chemistry, Case Western Reserve University, Cleveland, OH 44106, USA; E-Mails: shu.situ@case.edu (S.F.S.); eca20@case.edu (E.C.A.); mya.porche@case.edu (M.P.); Pawel.Kraj@live.mercer.edu (P.K.); Yutthana.Lakliang@case.edu (Y.L.)

3 Department of Chemistry, Mercer University, Macon, GA 31207, USA

* Authors to whom correspondence should be addressed;

E-Mails: dburke@holdenarb.org (D.J.B.); anna.samia@case.edu (A.C.S.S.);

Tel.: +1-440-602-3858 (D.J.B.); +1-216-368-3852 (A.C.S.S.);

Fax: +1-440-602-8005 (D.J.B.); +1-216-368-3006 (A.C.S.S.).

Academic Editor: Eleftherios P. Eleftheriou

Received: 30 July 2015 / Accepted: 25 September 2015 /Published: 5 October 2015

\begin{abstract}
In this study, we investigated the effect of positively and negatively charged $\mathrm{Fe}_{3} \mathrm{O}_{4}$ and $\mathrm{TiO}_{2}$ nanoparticles (NPs) on the growth of soybean plants (Glycine max.) and their root associated soil microbes. Soybean plants were grown in a greenhouse for six weeks after application of different amounts of NPs, and plant growth and nutrient content were examined. Roots were analyzed for colonization by arbuscular mycorrhizal (AM) fungi and nodule-forming nitrogen fixing bacteria using DNA-based techniques. We found that plant growth was significantly lower with the application of $\mathrm{TiO}_{2}$ as compared to $\mathrm{Fe}_{3} \mathrm{O}_{4} \mathrm{NPs}_{\text {. The }}$ leaf carbon was also marginally significant lower in plants treated with $\mathrm{TiO}_{2} \mathrm{NPs}$; however, leaf phosphorus was reduced in plants treated with $\mathrm{Fe}_{3} \mathrm{O}_{4}$. We found no effects of NP type, concentration, or charge on the community structure of either rhizobia or AM fungi colonizing plant roots. However, the charge of the $\mathrm{Fe}_{3} \mathrm{O}_{4} \mathrm{NPs}$ affected both colonization of the root system by rhizobia as well as leaf phosphorus content. Our results indicate that the type of NP can affect plant growth and nutrient content in an agriculturally important crop species, and that the charge of these particles influences the colonization of the root system
\end{abstract}


by nitrogen-fixing bacteria.

Keywords: iron oxide nanoparticles; titanium dioxide nanoparticles; arbuscular mycorrhizal fungi; Glycine max; microbial communities; nitrogen-fixing bacteria

\section{Introduction}

Metal oxide nanoparticles (NPs) are being increasingly used for commercial applications ranging from inclusion in self-cleaning coatings, topical sunscreens, and antimicrobial soaps [1-5]. With the large production of NPs for use in everyday consumer products, NP contamination in the environment is becoming an important matter of concern [3]. Studies have shown that these materials can have significant negative effects on both plants and soil microbes in agro-ecosystems but the effects of specific metal oxide NP types and the conditions under which negative effects may be observed have still not been well characterized [1,6,7]. Titanium dioxide $\left(\mathrm{TiO}_{2}\right)$ NPs, for example, produce reactive oxygen species when exposed to biological organisms or ultraviolet light. The reactive oxygen species can damage cell structures and DNA [8] and some studies have found negative effects of $\mathrm{TiO}_{2} \mathrm{NPs}$ on plant growth (e.g., reduced cell elongation, reduced transpiration and leaf growth) $[8,9]$. $\mathrm{TiO}_{2} \mathrm{NPs}_{\text {have also }}$ been shown to change the communities of soil bacteria and reduce the prevalence of some taxa involved in nitrogen fixation (e.g., Bradyrhizobium) [10]. Communities of important plant symbionts, such as arbuscular mycorrhizal (AM) fungi that colonize plant roots and enhance nutrient uptake have also been found to be affected by the application of $\mathrm{TiO}_{2} \mathrm{NPs}$ [11], which could have significant long-term effects on plant nutrient uptake and productivity in agro-ecosystems. On the other hand, some studies have reported no negative effects of $\mathrm{TiO}_{2} \mathrm{NPs}$ on plant growth, especially at low concentrations, as compared to other NPs such as Ag and ZnO NPs that had strong negative effects on plant growth including reduced root growth and elongation [12,13]. Although well studied to date, the effect of $\mathrm{TiO}_{2}$ NPs on plants is still not thoroughly understood.

Results of studies with other metal oxide NP types have observed greater negative effects on plant and microbial systems as compared to $\mathrm{TiO}_{2}$. For example, $\mathrm{ZnO}$ NPs have been the focus of a number of studies and generally, the application of $\mathrm{ZnO}$ has negative effects on plants. Boonyanitipong et al., found that the growth and elongation of rice roots were negatively affected by $\mathrm{ZnO}$ [12] and Lin and Xing found that ZnO NPs led to detrimental root growth termination of test plants [14]. Furthermore, the exposure of soybean plants to $\mathrm{ZnO}$ NPs led to a decrease in above ground and root mass, and altered the soil bacterial communities [15,16]. On the other hand, Ag NPs have also been found to be particularly toxic even at low concentrations. Kim et al. discovered that duckweed (Lemna paucicostata) cells experience the toxic effects of Ag NPs even at low 1 ppm concentrations, whereas toxic effects of $\mathrm{TiO}_{2} \mathrm{NPs}$ were not evident until concentrations $>250 \mathrm{ppm}$ [13]. Recent reports have indicated negative and positive effects of different types of NPs on plants in terms of their growth and seed germination [17]. Several factors have been shown to influence the plant-NP interactions, including plant type, growth media, as well as the NP concentration, size, and surface area. To date, there is still no conclusive explanation and definite mechanism on the toxicity of NPs in plants, 
particularly in the soil environment, and further studies are needed to explore the effects of NPs in relation to plant growth $[17,18]$.

NPs can alter soil microbial communities especially the microbes within the rhizosphere, which is the area of the soil in close proximity to the root that is under the influence of root exudates. Since plants rely upon these soil microbes for nutrient uptake (as is the case with AM fungi) or in the cycling and availability of nutrients like nitrogen $(\mathrm{N})$ or phosphorus $(\mathrm{P})$, changes in these soil microbes can have large effects on plants growth. As noted above, radical oxygen species liberated by NPs can damage cells and DNA, and some NPs can release heavy metals that can have toxic effects on microbial cells [19]. For example, the release of silver from NPs can inactivate enzymes, interfere with DNA replication, and alter cell membrane permeability, all of which can reduce microbial growth or have lethal effects on soil microbes. Although some NPs may be too large for microbes to absorb and assimilate, they can bind to the surface of cell membranes, altering membrane integrity and function. Various studies have demonstrated the toxic effects of different NPs on microbes in both the laboratory and field settings. Emami-Karvani and Chehrazi found that ZnO NPs affected gram positive bacteria more than gram negative bacteria, and that smaller sized NPs had greater antimicrobial effects [20]. Silver NPs are reported to be toxic to ammonifying and nitrogen fixing bacteria [6,21], and may disrupt microbial denitrification [6,21] and nitrogen-fixation [7]. Effects on the functional properties of soil microbes will depend on the composition and morphology of the NP under consideration and its local concentration. For example, Priester et al. found that $\mathrm{ZnO}$ had relatively little effect on nitrogen-fixation in a soybean crop system, but $\mathrm{CeO}_{2}$ had significant negative effects on nitrogen fixation at medium and high concentrations [7]. These studies suggest that toxic effects on soil microbes could be selective, and inhibition of certain microbial groups could alter soil microbial communities within the plant rhizosphere with negative consequences for plant nutrient uptake and soil fertility.

Although comparative studies on the effects of NPs have been performed, most studies are in culture or conducted under artificial conditions, and their applicability to plant-microbial responses in agroecosystems is uncertain. The work by Priester et al. demonstrates that additional comparative work, which simultaneously examines plant, microbial, and microbial functional processes in soil that underlie fertility, is greatly needed [7]. In this study, we report the results of a greenhouse experiment testing the effects of two important metal oxide $\mathrm{NPs}_{2} \mathrm{Fe}_{3} \mathrm{O}_{4}$ and $\mathrm{TiO}_{2}$, in a plant soil system using soybean (Glycine max.) as the test plant species. $\mathrm{Fe}_{3} \mathrm{O}_{4}$ is understudied within plant-soil systems and we wanted to examine the effects of this NP on plant growth and microbial communities in comparison to a better studied $\mathrm{TiO}_{2}$ NP system. We also examined the effects of different NP charges on the plant-soil system and the effects of NP concentration. We hypothesized that (1) treatment of soil with $\mathrm{Fe}_{3} \mathrm{O}_{4}$ would have fewer effects on plant growth and nutrient content of soybean compared to $\mathrm{TiO}_{2}$; (2) that both $\mathrm{Fe}_{3} \mathrm{O}_{4}$ and $\mathrm{TiO}_{2}$ would alter communities of microbes that grow in close association with plants (i.e., microbial symbionts) such as nitrogen-fixing bacteria (i.e., rhizobia) as well as AM fungi; and (3) that the concentration and charge of the NP would affect plant uptake of NP in roots and translocation to above ground plant tissue such as leaves and stems. In our study, the plant growth response was assessed by whole plant biomass and nutrient analysis, while root microbial community responses were determined using DNA-based methods or biomass measurements as needed. 


\section{Results and Discussion}

\subsection{Nanoparticle Synthesis and Surface Functionalization}

Iron oxide NPs were synthesized according to a previous reported procedure [22]. Monodisperse and spherical $\mathrm{Fe}_{3} \mathrm{O}_{4}$ NPs were prepared via a one-step thermal decomposition method. The average diameter of the $\mathrm{Fe}_{3} \mathrm{O}_{4} \mathrm{NPs}$ was evaluated to be $18 \mathrm{~nm}$ from transmission electron microscopy (TEM) analysis. The as-synthesized $\mathrm{Fe}_{3} \mathrm{O}_{4}$ NPs were capped with oleic acid and were later functionalized with amine- or carboxylic acid-terminating ligands through a silane ligand-based exchange water phase transfer process. The surface modification process yielded monodisperse $\mathrm{Fe}_{3} \mathrm{O}_{4}$ NPs with uniform shape and size (Figure 1a,b) and average hydrodynamic radius in the range of 21 to $23 \mathrm{~nm}$ as evaluated by dynamic light scattering (DLS) measurements (Figure 1c). The crystalline phase of the functionalized $\mathrm{Fe}_{3} \mathrm{O}_{4} \mathrm{NPs}_{\text {sas confirmed }}$ to be magnetite $\left(\mathrm{Fe}_{3} \mathrm{O}_{4}\right)$ through powder X-ray diffractometry (XRD) and Rietveld analysis (Figure 1d). The Fourier transform infrared (FTIR) spectra of the functionalized $\mathrm{Fe}_{3} \mathrm{O}_{4}$ NPs showed the $\mathrm{NH}_{2}(1570$ $\left.\mathrm{cm}^{-1}\right)$ and $\mathrm{C}=\mathrm{O}\left(1670-1820 \mathrm{~cm}^{-1}\right)$ vibrational stretch peaks characteristic of amine- and carboxylic acidfunctional groups (Figure 1e). The resulting amine- and carboxylic acid-functionalized $\mathrm{Fe}_{3} \mathrm{O}_{4}$ NPs carried positive and negative surface charges, respectively, as confirmed from zeta potential measurements (Figure 1f).
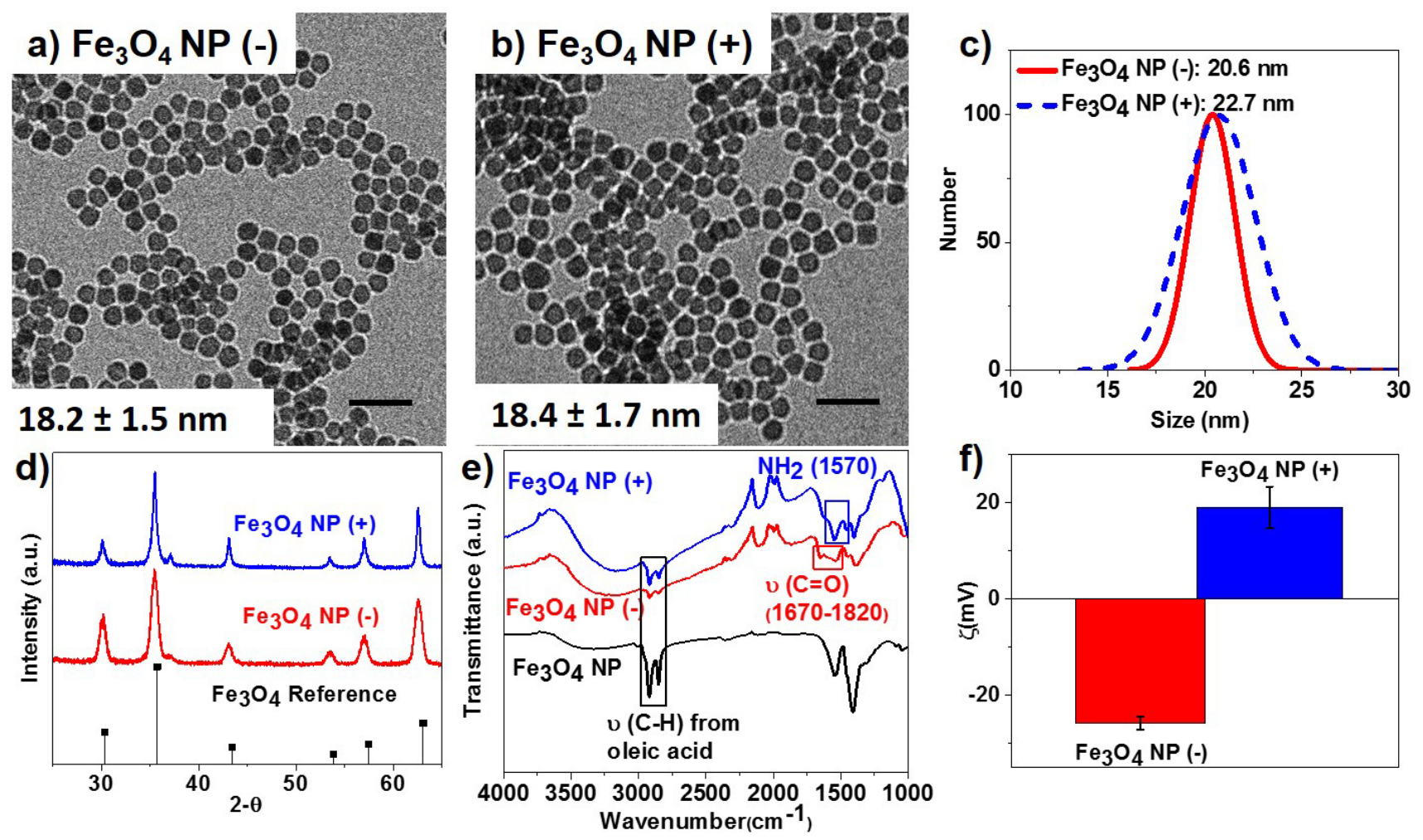

Figure 1. (a,b) Transmission electron micrographs of magnetite nanoparticles (NPs) $\left(\mathrm{Fe}_{3} \mathrm{O}_{4}\right)$ functionalized with $\mathrm{COOH}(-)$ and $\mathrm{NH}_{2}(+)$ groups, respectively. Scale bars are 50 nm; (c) Dynamic light scattering measurements; (d) powder X-ray diffraction patterns; (e) Fourier transform infrared (FTIR) spectra; and (f) zeta potential measurements of the synthesized $\mathrm{Fe}_{3} \mathrm{O}_{4} \mathrm{NP}(-)$ and $\mathrm{Fe}_{3} \mathrm{O}_{4} \mathrm{NP}(+)$ samples, respectively. 
On the other hand, commercially available $\mathrm{TiO}_{2}$ Degussa P25 NPs (Evonik) were similarly modified with amine and carboxylic acid based silane ligands to generate positive and negatively charged $\mathrm{TiO}_{2}$ NPs. The size, morphology, and crystalline phase of the NPs were investigated using TEM, DLS, and powder XRD. The $\mathrm{TiO}_{2} \mathrm{P} 25$ NPs have particle sizes in the range of 22 and $25 \mathrm{~nm}$ based on TEM analyses (Figure 2a,b), while DLS measurements indicated the formation of large aggregates in the size range of 147 to $340 \mathrm{~nm}$ for the $\mathrm{TiO}_{2}$ NPs in solution (Figure 2c). XRD analyses showed the $\mathrm{TiO}_{2} \mathrm{NPs}$ indexing well to the crystalline anatase phase as well as that of rutile (Figure 2d). FTIR analysis showed the successful surface modification of the NPs (Figure 2e) while zeta potential measurements confirmed the surface charge of the NPs (Figure 2f).
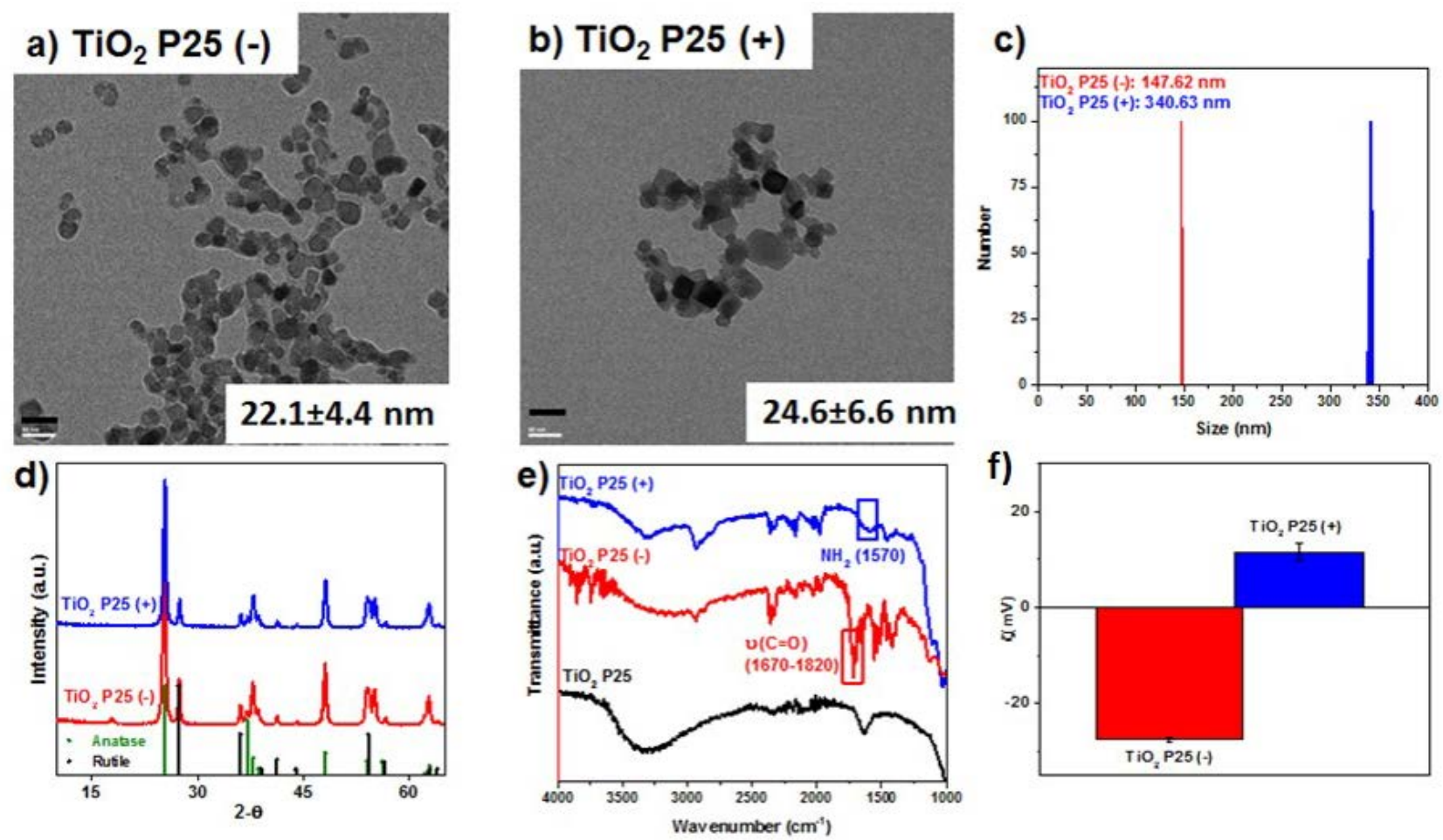

Figure 2. (a,b) Transmission electron micrographs of Degussa P25 $\left(\mathrm{TiO}_{2}\right)$ functionalized with $\mathrm{COOH}(-)$ and $\mathrm{NH}_{2}(+)$ groups, respectively. Scale bars are $50 \mathrm{~nm}$; (c) dynamic light scattering measurements; (d) powder X-ray diffraction patterns; (e) FTIR spectra; and (f) zeta potential measurements of $\mathrm{TiO}_{2} \mathrm{P} 25(-)$ and $\mathrm{TiO}_{2} \mathrm{P} 25(+)$ samples, respectively.

\subsection{Plant Growth and Nutrient Analysis}

Above ground dry biomass was significantly affected by NP type (three-way ANOVA, $F=6.5$,

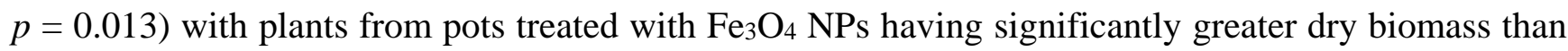
plants treated with $\mathrm{TiO}_{2}$ NPs $\left(3.29 \pm 0.16 \mathrm{~g} \cdot \operatorname{pot}^{-1}\right.$ for $\mathrm{Fe}_{3} \mathrm{O}_{4}$ versus $2.69 \pm 0.18 \mathrm{~g} \cdot \mathrm{pot}^{-1}$ for $\left.\mathrm{TiO}_{2}\right)$ (Table 1). Root dry biomass was also marginally significant higher (three-way ANOVA, $F=3.2$, $p=0.078)$ in plants treated with $\mathrm{Fe}_{3} \mathrm{O}_{4}\left(0.64 \pm 0.04 \mathrm{~g} \cdot\right.$ pot $^{-1}$ for $\mathrm{Fe}_{3} \mathrm{O}_{4}$ versus $0.54 \pm 0.03 \mathrm{~g} \cdot$ pot $^{-1}$ for $\mathrm{TiO}_{2}$ ). Although leaf $\mathrm{N}$ content was unaffected by treatment, leaf $\mathrm{C}$ content was marginally significant higher (three-way ANOVA, $F=3.4, p=0.069$ ) in $\mathrm{Fe}_{3} \mathrm{O}_{4}$ treated as compared to $\mathrm{TiO}_{2}$ treated plants (43.02 $\pm 0.11 \mathrm{~g} \cdot$ pot $^{-1}$ for $\mathrm{Fe}_{3} \mathrm{O}_{4}$ versus $42.63 \pm 0.19 \mathrm{~g} \cdot \mathrm{pot}^{-1}$ for $\mathrm{TiO}_{2}$ ) (Table 1, Figure 3a,b). Charge and 
NP concentration had no significant effect on above ground dry biomass, root dry biomass, or leaf $\mathrm{C}$ and $\mathrm{N}$ content. We found that both NP type and charge had significant effects on leaf $\mathrm{P}$ content (three-way ANOVA, $F=84.3, p<0.001$ NP type; $F=4.2, p=0.047$ NP charge). Leaf $\mathrm{P}$ was greater in $\mathrm{TiO}_{2}$ treatments as compared to $\mathrm{Fe}_{3} \mathrm{O}_{4}$ treatments $\left(2738.8 \pm 144.0 \mu \mathrm{g} \cdot \mathrm{P} \cdot \mathrm{g}^{-1}\right.$ leaf dry weight for $\mathrm{TiO}_{2}$ versus $984.1 \pm 125.8 \mu \mathrm{g} \cdot \mathrm{P} \cdot \mathrm{g}^{-1}$ leaf dry weight for $\mathrm{Fe}_{3} \mathrm{O}_{4}$ ) and leaf $\mathrm{P}$ was greater in plants that received negatively charged NPs $\left(2056.7 \pm 145.4 \mu \mathrm{g} \cdot \mathrm{P} \cdot \mathrm{g}^{-1}\right.$ leaf dry weight for negative versus $1666.2 \pm 124.0 \mu \mathrm{g} \cdot \mathrm{P} \cdot \mathrm{g}^{-1}$ leaf dry weight for positive) (Table 1 , Figure 3c,d). We also saw a marginally significant metal $\times$ concentration effect on leaf $\mathrm{P}$ (Table 1). Further, two-way ANOVA of NP type performed separately (Table 2) found that within NP type (i.e., $\mathrm{Fe}_{3} \mathrm{O}_{4}$ or $\mathrm{TiO}_{2}$ ), plant dry biomass and leaf $\mathrm{C}$ and $\mathrm{N}$ content were not affected by NP concentration or charge. However, leaf $\mathrm{P}$ content was significantly affected by both concentration and charge within the $\mathrm{Fe}_{3} \mathrm{O}_{4}$ treatments. Leaf $\mathrm{P}$ content in control and plants exposed to $200 \mathrm{mg}$ of $\mathrm{Fe}_{3} \mathrm{O}_{4}$ NPs had approximately equivalent leaf $\mathrm{P}$ content but leaf $\mathrm{P}$ content was significantly higher in plants exposed to $100 \mathrm{mg}$ of $\mathrm{Fe}_{3} \mathrm{O}_{4} \mathrm{NPs}$ (715.4 $\pm 153.8 \mu \mathrm{g} \cdot \mathrm{P} \cdot \mathrm{g}^{-1}$ leaf dry weight, control leaf $\mathrm{P} ; 1470.7 \pm 153.8 \mu \mathrm{g} \cdot \mathrm{P} \cdot \mathrm{g}^{-1}$ leaf dry weight for 100 $\mathrm{mg} \mathrm{Fe}_{3} \mathrm{O}_{4} \mathrm{NP} ; 766.1 \pm 144.3 \mu \mathrm{g} \cdot \mathrm{P} \cdot \mathrm{g}^{-1}$ leaf dry weight for $200 \mathrm{mg} \mathrm{Fe}_{3} \mathrm{O}_{4} \mathrm{NP}$ ) (Figure 3c,d). Plants receiving negatively charged $\mathrm{Fe}_{3} \mathrm{O}_{4}$ NPs also had significantly higher leaf $\mathrm{P}$ content than did plants receiving positively charged $\mathrm{Fe}_{3} \mathrm{O}_{4} \mathrm{NPs}\left(1207.5 \pm 132.9 \mu \mathrm{g} \cdot \mathrm{P} \cdot \mathrm{g}^{-1}\right.$ leaf dry weight, negatively charged $\mathrm{Fe}_{3} \mathrm{O}_{4} ; 760.6 \pm 116.0 \mu \mathrm{g} \cdot \mathrm{P} \cdot \mathrm{g}^{-1}$ leaf dry weight, positively charged $\mathrm{Fe}_{3} \mathrm{O}_{4}$ ) (Table 2, Figure 3c,d).
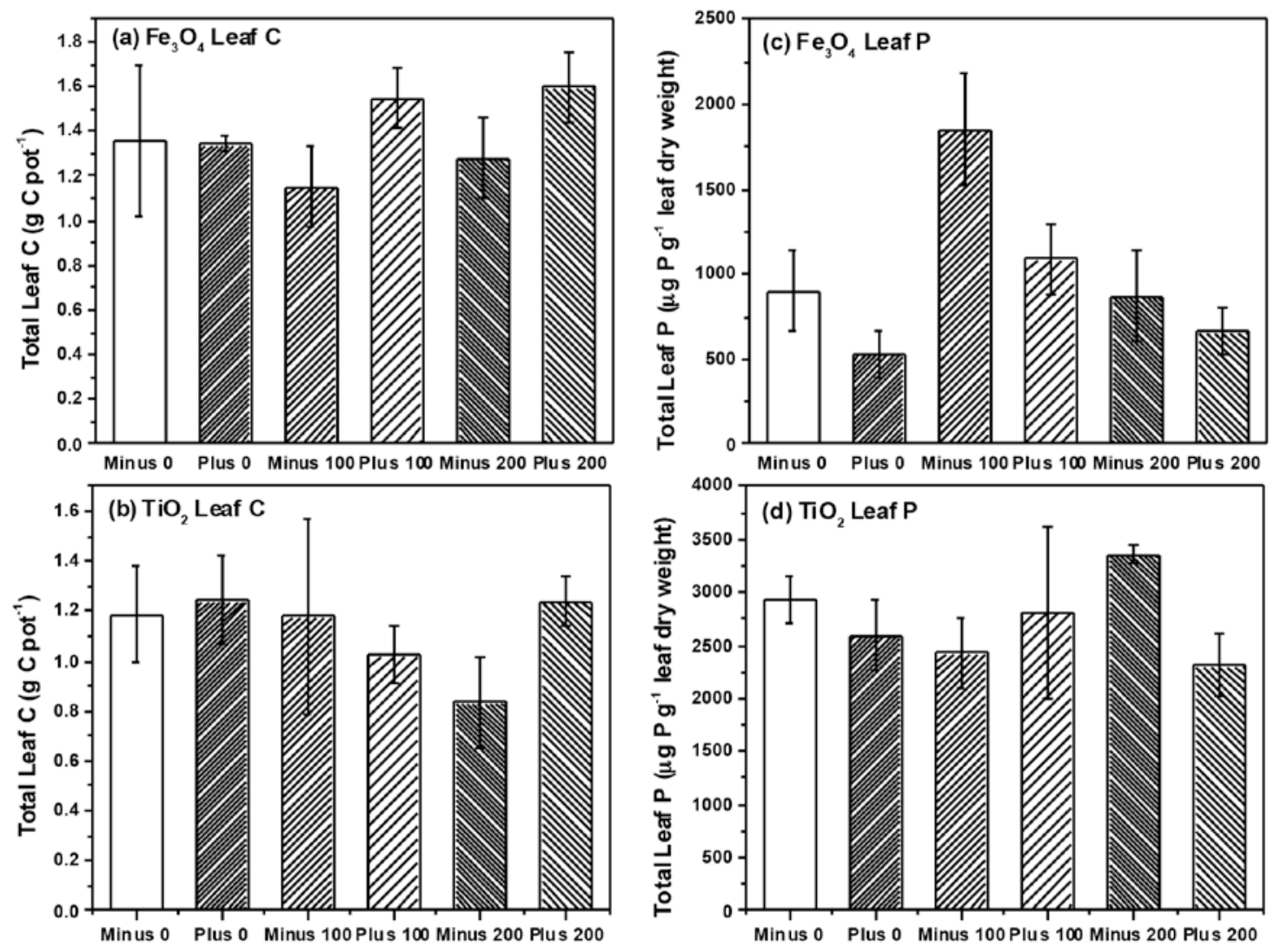

Figure 3. The carbon contents found in the leaf from soybean plants treated with (a) $\mathrm{Fe}_{3} \mathrm{O}_{4}$ and (b) $\mathrm{TiO}_{2}$ NPs, respectively; the phosphorus contents found in the leaf from soybean plants treated with (c) $\mathrm{Fe}_{3} \mathrm{O}_{4}$ and (d) $\mathrm{TiO}_{2}$ NPs, respectively. 
Table 1. Results of three-way ANOVA using the general linear model for effects of nanoparticle concentration and charge on plant growth performance. $p$ values are shown where significant differences $(p<0.1)$ are in bold. Note: nutrient contents refer to leaf tissue only. (Above $\mathrm{Wt}=$ weight of plant tissue above ground, Root $\mathrm{Wt}=$ weight of roots, Nodule $\mathrm{Wt}=$ weight of nodule, Nodule/Root $=$ nodule weight per root mass, $\mathrm{AM} \mathrm{Col}=$ arbuscular mycorrhizal colonization).

\begin{tabular}{ccccccccc}
\hline Source of Variation & $\begin{array}{c}\text { Above } \\
\text { Wt }^{\mathbf{1}}\end{array}$ & $\begin{array}{c}\text { Root } \\
\text { Wt }\end{array}$ & $\begin{array}{c}\text { Nodule } \\
\text { Wt }\end{array}$ & $\begin{array}{c}\text { Nodule/ } \\
\text { Root }^{2}\end{array}$ & $\begin{array}{c}\mathbf{A M} \\
\mathbf{C o l}^{3}\end{array}$ & C $^{4}$ & \multirow{2}{*}{$\mathbf{N}$} & \multirow{2}{*}{$\mathbf{P}$} \\
\hline Metal Type & $\mathbf{0 . 0 1 3}$ & $\mathbf{0 . 0 7 8}$ & 0.222 & 0.866 & 0.199 & $\mathbf{0 . 0 6 9}$ & 0.808 & $<\mathbf{0 . 0 0 1}$ \\
Metal Concentration & 0.730 & 0.618 & 0.750 & 0.157 & 0.750 & 0.465 & 0.662 & 0.370 \\
Metal Charge & 0.373 & 0.228 & $\mathbf{0 . 0 8 2}$ & $\mathbf{0 . 0 7 3}$ & 0.878 & 0.110 & 0.938 & $\mathbf{0 . 0 4 7}$ \\
Metal $\times$ Concentration & 0.587 & 0.590 & 0.722 & 0.421 & 0.163 & 0.240 & 0.641 & $\mathbf{0 . 0 9 3}$ \\
Metal $\times$ Charge & 0.591 & 0.945 & 0.777 & 0.511 & 0.245 & 0.242 & 0.327 & 0.769 \\
Concentration $\times$ Charge & 0.182 & 0.317 & 0.396 & 0.559 & 0.171 & 0.194 & 0.570 & 0.665 \\
Metal $\times$ Conc. $\times$ charge & 0.100 & 0.972 & 0.322 & 0.225 & 0.630 & 0.234 & 0.977 & 0.134 \\
\hline
\end{tabular}

${ }^{1}$ Plant tissue and nodule weight are reported on a dry weight basis per pot; ${ }^{2}$ nodule colonization: nodule dry weight/root dry weight; ${ }^{3}$ AM colonization: copy numbers of $18 \mathrm{~S}$ rDNA per gram of dry root tissue. Data was natural $\log$ transformed to meet normality assumptions; ${ }^{4} \mathrm{C}$ and $\mathrm{N}$ data are \% $\mathrm{C}$ and $\mathrm{N}$ leaf data log transformed prior to analysis.

Table 2. Results of two-way ANOVA using the general linear model for effects of nanoparticle concentration and charge on plant growth performance. $p$ values are shown where significant differences $(p<0.1)$ are in bold. Note: nutrient contents refer to leaf tissue only.

\begin{tabular}{ccccccccc}
\hline Source of Variation & $\begin{array}{c}\text { Above } \\
\mathbf{W t}^{\mathbf{1}}\end{array}$ & $\begin{array}{c}\text { Root } \\
\text { Wt }\end{array}$ & $\begin{array}{c}\text { Nodule } \\
\text { Wt }\end{array}$ & $\begin{array}{c}\text { Nodule/ } \\
\text { Root }^{2}\end{array}$ & $\begin{array}{c}\mathbf{A M} \\
\text { Col }^{3}\end{array}$ & C $^{\mathbf{4}}$ & N & P \\
\hline $\mathrm{Fe}_{3} \mathrm{O}_{4}$ Concentration & 0.772 & 0.647 & 0.749 & 0.257 & 0.842 & 0.528 & 0.778 & $\mathbf{0 . 0 0 3}$ \\
$\mathrm{Fe}_{3} \mathrm{O}_{4}$ Charge & 0.284 & 0.494 & 0.152 & $\mathbf{0 . 0 5 7}$ & 0.188 & $\mathbf{0 . 0 1 0}$ & 0.387 & $\mathbf{0 . 0 1 8}$ \\
Concentration $\times$ Charge & 0.138 & 0.590 & 0.307 & 0.258 & 0.604 & 0.887 & 0.507 & 0.442 \\
$\mathrm{TiO}_{2}$ Concentration & 0.578 & 0.521 & 0.719 & 0.267 & 0.156 & 0.297 & 0.631 & 0.899 \\
$\mathrm{TiO}_{2}$ Charge & 0.814 & 0.252 & 0.309 & 0.462 & 0.412 & 0.805 & 0.547 & 0.377 \\
Concentration $\times$ Charge & 0.159 & 0.475 & 0.441 & 0.460 & 0.479 & 0.157 & 0.863 & 0.350 \\
\hline
\end{tabular}

${ }^{1}$ Plant tissue and nodule weight are reported on a dry weight basis per pot; ${ }^{2}$ nodule colonization: nodule dry weight/root dry weight; ${ }^{3}$ AM colonization: copy numbers of $18 \mathrm{~S}$ rDNA per gram of dry root tissue. Data was natural $\log$ transformed to meet normality assumptions; ${ }^{4} \mathrm{C}$ and $\mathrm{N}$ data are $\% \mathrm{C}$ and $\mathrm{N}$ leaf data $\log$ transformed prior to analysis.

\subsection{Analysis of Microbial Communities}

We detected a total of 15 TRFs in our root samples representing AM taxa. Non-metric multidimensional scaling (NMS) analysis resulted in a final stress of 10.1 and a three dimensional solution. However, we found no effect of NP type (i.e., $\mathrm{Fe}_{3} \mathrm{O}_{4}$ or $\mathrm{TiO}_{2}$ ), concentration or charge on AM root communities (data not shown). Multi-response permutation procedures (MRPP) analysis confirmed a lack of treatment effects on the AM root communities. Our analysis also failed to find any 
effects of NP type, charge or concentration on AM root colonization (Tables 1 and 2), although AM colonization tended to increase with $\mathrm{Fe}_{3} \mathrm{O}_{4} \mathrm{NP}$ concentration but decrease with $\mathrm{TiO}_{2} \mathrm{NP}$ concentration. We also analyzed a subset ( $n=37$ plants) of root nodules for differences in rhizobia communities using NMS and MRPP. NMS resulted in a two-dimensional solution with a final stress of 3.9 and we were able to detect five different rhizobia taxa within the roots of soybean. However, we found no effects of NP type, concentration or charge on rhizobia communities using NMS and confirmed through MRPP (Data not shown). We did, however, find a marginally significant effect of NP charge on nodule dry weight and nodule root colonization (three-way ANOVA, $F=3.1, p=0.082$ nodule dry weight; $F=3.3, p=0.073$ NP nodule colonization) (Table 1). Two-way ANOVA found that nodule colonization was significantly higher in plants that received positively charged $\mathrm{Fe}_{3} \mathrm{O}_{4} \mathrm{NPs}$ $\left(0.337 \pm 0.02\right.$ g dry weight per gram root dry weight, positively charged $\mathrm{Fe}_{3} \mathrm{O}_{4} ; 0.275 \pm 0.02$ g per gram root dry weight, negatively charged $\mathrm{Fe}_{3} \mathrm{O}_{4}$ ) but application of $\mathrm{TiO}_{2}$ NPs had no effect on nodule colonization.

The metal oxide NP type had different effects on plant growth, nutrient uptake, and colonization by soil microbes. To better examine the phytotoxicity effect of soil contaminated by NPs, we have chosen to grow the soybean plants in soil with $\mathrm{TiO}_{2}$ and $\mathrm{Fe}_{3} \mathrm{O}_{4}$ NPs treatments that were applied as water suspension to mimic the condition of soil contamination by NP run offs. Such an application method has been commonly used in previous soil-based plant studies and has provided sufficient exposure and bioavailability of the NPs to the plants [7,23,24]. We found that $\mathrm{TiO}_{2} \mathrm{NPs}$ significantly reduced plant growth as compared to $\mathrm{Fe}_{3} \mathrm{O}_{4}$ and these changes were also accompanied by reductions in leaf C content. NP types have been found to differentially affect plant growth in previous studies. For example, Priester et al. found that $\mathrm{CeO}_{2}$ NPs reduced plant growth and impaired N-fixing ability of soybean while $\mathrm{ZnO}$ NPs did not affect growth (although ZnO NPs did accumulate in above ground plant tissue) [7]. We previously found no significant effects of $\mathrm{TiO}_{2}$ NPs on plant growth at similar concentrations to those used in the current study [11], and dry biomass was also similar after a comparable growth period (e.g., $2.94 \pm 0.21 \mathrm{~g}$ pot $^{-1} \mathrm{TiO}_{2}$ treated above ground dry biomass) although root growth in our previous study was $2 \times$ lower than what we report here. It is possible that the significantly reduced dry biomass within the $\mathrm{TiO}_{2} \mathrm{NP}$ treatment does not reflect a reduction in growth with exposure to $\mathrm{TiO}_{2}$, but rather stimulation in plant growth with exposure to $\mathrm{Fe}_{3} \mathrm{O}_{4}$. Several studies have reported positive effects of NP on plant growth. Hong et al. reported that spinach leaves treated with $\mathrm{TiO}_{2}$ NPs had higher levels of photosynthesis compared to untreated leaves, whereas Lu et al. reported increased levels of nitrate reductase activity in the rhizosphere of soybean roots treated with $\mathrm{TiO}_{2}$ NPs $[25,26]$. Studies of this type have suggested that treating plants with some NPs may improve plant growth and productivity [25-28]. Although we found no evidence for improved growth with $\mathrm{TiO}_{2}$ application, improved growth with $\mathrm{Fe}_{3} \mathrm{O}_{4}$ application could have resulted from changes in plant Fe status (Figure 4). Fe is a needed plant micronutrient [29], although it is usually not deficient except on calcareous soils. Increasing amounts of $\mathrm{Fe}_{3} \mathrm{O}_{4}$ could have had direct effects on plant growth increasing both above- and below-ground growth relative to $\mathrm{TiO}_{2}$ plants. It seems unlikely that growth increases would be due to changes in nutrient availability with NP application since leaf N was unaffected by NP type, concentration or charge, and leaf $\mathrm{P}$ was actually lower in $\mathrm{Fe}_{3} \mathrm{O}_{4}$ treated plants, where charge actually influenced leaf $\mathrm{P}$ content. Overall reductions in leaf $\mathrm{P}$ could be the result of $\mathrm{Fe}_{3} \mathrm{O}_{4}$ binding to soil $\mathrm{P}$ under acidic conditions, creating $\mathrm{FePO}_{4}$ complexes within the soil [30]. This could have reduced 
overall plant $\mathrm{P}$ acquisition relative to plants treated with $\mathrm{TiO}_{2} \mathrm{NP}$ but growth increased despite these declines in leaf $\mathrm{P}$ (and no change in leaf $\mathrm{N}$ as noted above). Growth increases in the $\mathrm{Fe}_{3} \mathrm{O}_{4}$ plants was accompanied by marginally significant increases in leaf $\mathrm{C}$, suggesting that increased $\mathrm{C}$ fixation could have contributed to the growth increases in the $\mathrm{Fe}_{3} \mathrm{O}_{4}$ plants despite leaf $\mathrm{P}$ reductions. Fe is necessary for the production of chlorophyll [31] and increased chlorophyll content could have led to greater C fixation and the growth increases we observed. More detailed analysis of plant photosynthesis and gas exchange would be needed to ascertain the cause of the growth increases with $\mathrm{Fe}_{3} \mathrm{O}_{4}$ application relative to $\mathrm{TiO}_{2}$.
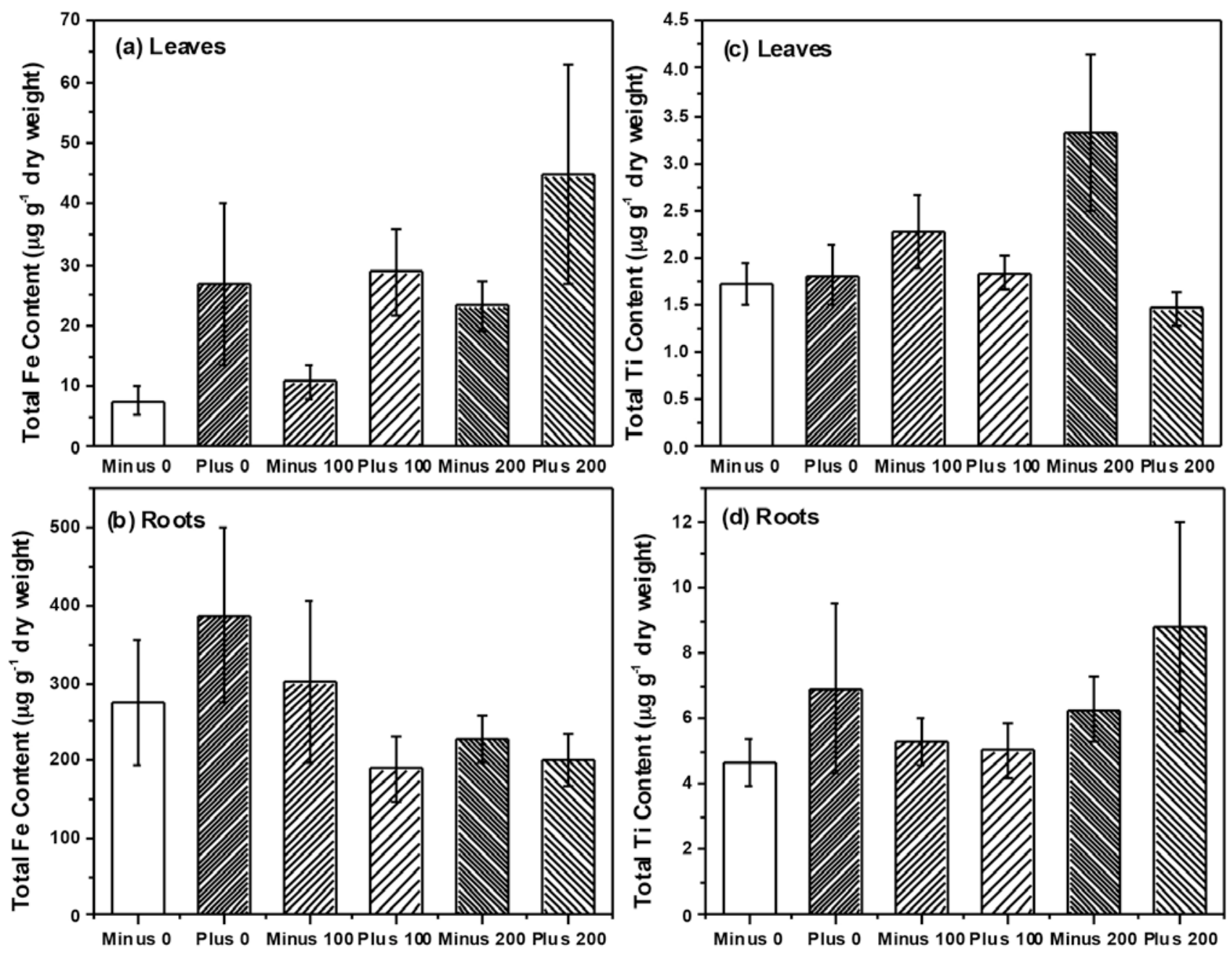

Figure 4. Total amount of Fe found in leaves (a) and roots (b) and the total amount of $\mathrm{Ti}$ found in leaves (c) and roots (d), respectively.

As expected, we found that roots contained significantly higher levels of NP as compared to leaves, and this was the case for both NP examined (Table 3, Figure 4). Plants accumulated much more Fe than $\mathrm{Ti}$ (Figure 4), but given the fact that plants excrete organic compounds to solubilize and facilitate $\mathrm{Fe}$ uptake [31], high levels of Fe in root tissue, especially in comparison to Ti may not be unexpected. We detected very little transfer of Ti into the leaf tissue and there was no effect of charge or concentration on the leaf Ti levels. However, of interest were the effects of charge on Fe transfer into leaves. Although charge had no effect on root Fe concentrations, plants treated with negatively charged $\mathrm{Fe}_{3} \mathrm{O}_{4} \mathrm{NPs}_{\text {had }}$ 
significantly more Fe in leaf tissue (Table 3) than did plants treated with positively charged $\mathrm{Fe}_{3} \mathrm{O}_{4} \mathrm{NPs}$, suggesting that NP charge can affect the plant translocation of metals. ZnO NPs were found to be translocated by the plant into above ground plant tissue but $\mathrm{CeO}_{2} \mathrm{NPs}$ were not [7], suggesting that NP type could also affect uptake and translocation. In our previous study, we found some evidence that doping $\mathrm{TiO}_{2}$ NPs with $\mathrm{N}$ could also affect plant translocation of NPs to above ground plant tissue [11]. Within our current study, we found that NP charge could also affect NP translocation. In addition, similar to the findings of other groups [32], the NP size also greatly influences the plant uptake. In our study, the $\mathrm{TiO}_{2} \mathrm{NPs}$ formed large aggregates in the size range of $147-330 \mathrm{~nm}$ as evaluated from DLS analysis. In comparison, the $\mathrm{Fe}_{3} \mathrm{O}_{4}$ NPs that we used in our study have the hydrodynamic radius in the range of $22-25 \mathrm{~nm}$. As a consequence of the large difference in size range, one can infer that the $\mathrm{Fe}_{3} \mathrm{O}_{4} \mathrm{NPs}_{\text {sill }}$ be more likely to be available for the plant uptake because of its relatively larger surface area. This is reflected in our results where you can see a significant effect of NP concentration with the application of $\mathrm{Fe}_{3} \mathrm{O}_{4} \mathrm{NPs}$ as compared to the plant exposed to $\mathrm{TiO}_{2} \mathrm{NPs}$. These collective data suggest that the plant uptake of NPs will be context specific, depending both on the type, size, charge, and chemical surface structure of the NP, but that all factors may affect uptake and translocation.

Table 3. Results of three-way ANOVA using the general linear model for effects of plant tissue (root or leaf), nanoparticle concentration, and nanoparticle charge on plant tissue metal concentrations. $p$ values are shown where significant differences $(p<0.1)$ are in bold. Data for $\mathrm{Fe}_{3} \mathrm{O}_{4}$ were log transformed to meet normality assumptions.

\begin{tabular}{|c|c|c|c|c|c|c|}
\hline Variable & Source of Variation & DF & SS & MS & $F$ & $p$ \\
\hline \multirow[t]{9}{*}{$\mathrm{Fe}$} & Plant Tissue & 1 & 24.306 & 24.306 & 216.747 & $<0.001$ \\
\hline & $\mathrm{Fe}_{3} \mathrm{O}_{4}$ Concentration & 2 & 0.138 & 0.0691 & 0.616 & 0.543 \\
\hline & $\mathrm{Fe}_{3} \mathrm{O}_{4}$ Charge & 1 & 0.379 & 0.379 & 3.381 & 0.071 \\
\hline & Tissue $\times$ Concentration & 2 & 0.624 & 0.312 & 2.783 & 0.070 \\
\hline & Tissue $\times$ Charge & 1 & 0.496 & 0.496 & 4.424 & 0.040 \\
\hline & Concentration $\times$ Charge & 2 & 0.293 & 0.147 & 1.308 & 0.278 \\
\hline & Tissue $\times$ Conc.$\times$ Charge & 2 & 0.182 & 0.0911 & 0.812 & 0.449 \\
\hline & Residual & 60 & 6.728 & 0.112 & & \\
\hline & Total & 71 & 33.148 & 0.467 & & \\
\hline \multirow[t]{9}{*}{$\mathrm{Ti}$} & Plant Tissue & 1 & 275.862 & 275.862 & 25.317 & $<0.001$ \\
\hline & $\mathrm{TiO}_{2}$ Concentration & 2 & 23.532 & 11.766 & 1.080 & 0.347 \\
\hline & $\mathrm{TiO}_{2}$ Charge & 1 & 2.492 & 2.492 & 0.229 & 0.634 \\
\hline & Tissue $\times$ Concentration & 2 & 10.868 & 5.434 & 0.499 & 0.610 \\
\hline & Tissue $\times$ Charge & 1 & 20.869 & 20.869 & 1.915 & 0.172 \\
\hline & Concentration $\times$ Charge & 2 & 6.466 & 3.233 & 0.297 & 0.744 \\
\hline & Tissue $\times$ Conc.$\times$ Charge & 2 & 11.798 & 5.899 & 0.541 & 0.585 \\
\hline & Residual & 55 & 599.305 & 10.896 & & \\
\hline & Total & 66 & 971.381 & 14.718 & & \\
\hline
\end{tabular}


In our previous work, we found significant effects of $\mathrm{TiO}_{2} \mathrm{NPs}$ on communities of AM fungi in soil surrounding plant roots (i.e., rhizosphere soil) [11]. Although we found no effect on rhizosphere bacteria communities, our findings were in agreement with a number of studies that have observed effects of NP on soil microbes and their activity $[7,10,11]$. However, in our current study we specifically examined two groups of microbial plants mutualists and their colonization and community structure on or within the root tissue itself, and not in soil. We felt that by examining microbes colonizing roots, we would have a better sense of the functional effects of NPs (e.g., nutrient uptake, availability with rhizobia) than examination of soil communities only. Surprisingly, we found little effect on the community structure for either AM fungi (Figure 5) or for rhizobia (Figure 6) colonizing the root system, which is in contrast to our previous work and that of others $[10,11]$. However, bacteria and fungi within the root tissue could be protected from the direct toxic effects of NPs if the chemical form or concentration of the NP differs inside and outside the root. In our study, Fe concentration within the root ranged between 200-400 $\mu \mathrm{g} \cdot \mathrm{Fe} \cdot \mathrm{g}^{-1}$ root tissue while soil concentrations also ranged between $200-400 \mu \mathrm{g} \cdot \mathrm{Fe} \cdot \mathrm{g}^{-1}$ soil. Consequently, the root analysis reflected the Fe concentration in the soil, while the Ti concentration within the roots were considerably less than the amount in the soil (200-400 $\mu \mathrm{g} \cdot \mathrm{Ti} \cdot \mathrm{g}^{-1}$ soil as compared to $5-10 \mu \mathrm{g} \cdot \mathrm{Ti}^{-\mathrm{g}^{-1}}$ root tissue). Therefore, microbes within plant roots could have been protected against the toxic effects of $\mathrm{TiO}_{2} \mathrm{NPs}$ since root concentrations were far less than in the soil, but this was not the case for $\mathrm{Fe}_{3} \mathrm{O}_{4} \mathrm{NP}$ treatment. When examining colonization of roots directly, $\mathrm{AM}$ colonization tended to increase with $\mathrm{Fe}_{3} \mathrm{O}_{4} \mathrm{NP}$ application and decrease with $\mathrm{TiO}_{2} \mathrm{NP}$ application but these differences were not significant. In regards to rhizobia, we did observe a significant increase in nodule dry weight and colonization when exposed to positively charged $\mathrm{Fe}_{3} \mathrm{O}_{4} \mathrm{NP}$; a pattern not seen with $\mathrm{TiO}_{2} \mathrm{NP}$ application (Figure 6). Although Priester et al. saw declines in $\mathrm{N}$-fixation with $\mathrm{CeO}_{2}$ application, these declines were evident at only high concentrations and absent in $\mathrm{ZnO}$ application [7]. Lu et al. did report higher levels of nitrate reductase activity in the rhizosphere of soybean roots treated with $\mathrm{TiO}_{2}$ NPs, suggesting that NP could increase activity of some bacterial groups and have functional effects on soil nutrient availability [26]. Although we did not measure $\mathrm{N}$-fixation per se, our results suggest that application of positively charged NPs could increase the rhizobia nodule dry weight per unit root weight of soybean roots, at least in comparison to the negatively charged $\mathrm{Fe}_{3} \mathrm{O}_{4}$ NPs. However, these results are only marginally significant and further study is necessary. One possible reason for the increase in rhizobia with $\mathrm{Fe}_{3} \mathrm{O}_{4} \mathrm{NP}$ is that $\mathrm{Fe}$ is an essential micronutrient for nitrogen-fixing bacteria [33], and positively charged $\mathrm{Fe}_{3} \mathrm{O}_{4} \mathrm{NP}$ could be providing these bacteria with an essential micronutrient, thus resulting in increased growth and colonization as we observed. We cannot discount, however, the possibility that positively charged $\mathrm{Fe}_{3} \mathrm{O}_{4} \mathrm{NPs}_{\text {adhere to the }}$ surface of the root nodules to a greater extent than negatively charged $\mathrm{Fe}_{3} \mathrm{O}_{4} \mathrm{NPs}$ and this could explain the differences in the observed nodule dry weights. 

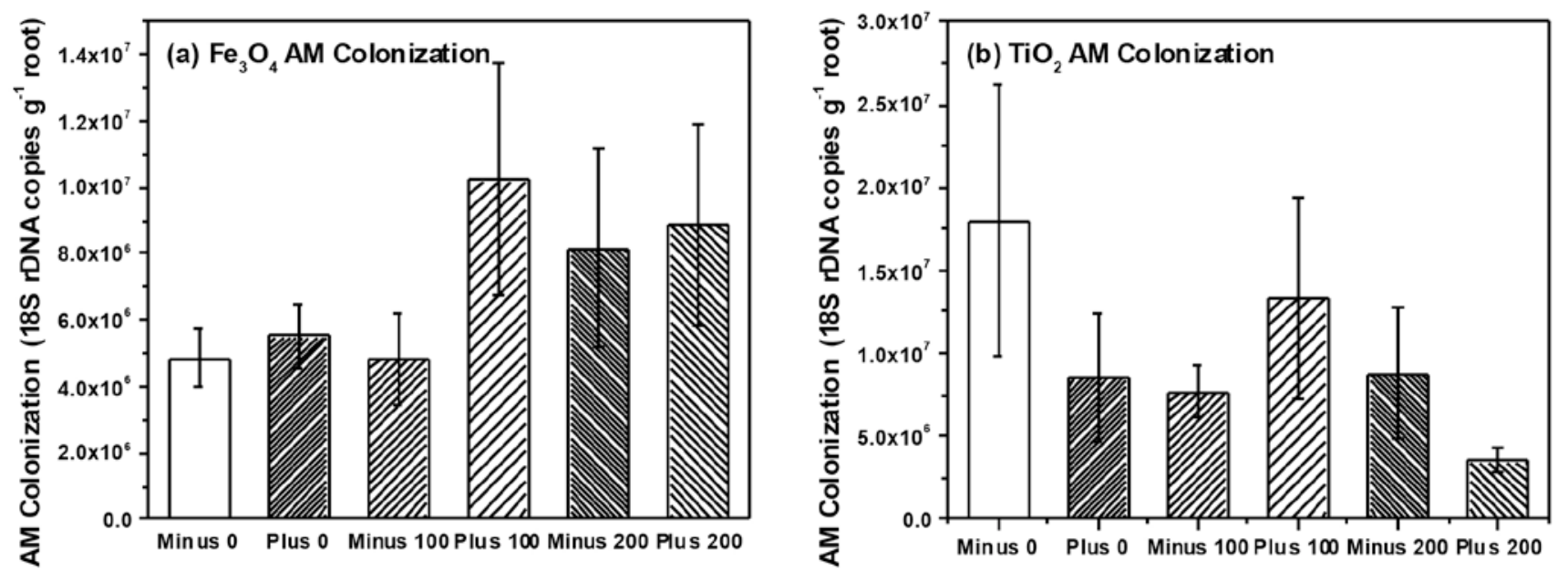

Figure 5. AM colonization in soybean plants treated with (a) $\mathrm{Fe}_{3} \mathrm{O}_{4}$ and (b) $\mathrm{TiO}_{2}$ NPs, respectively.
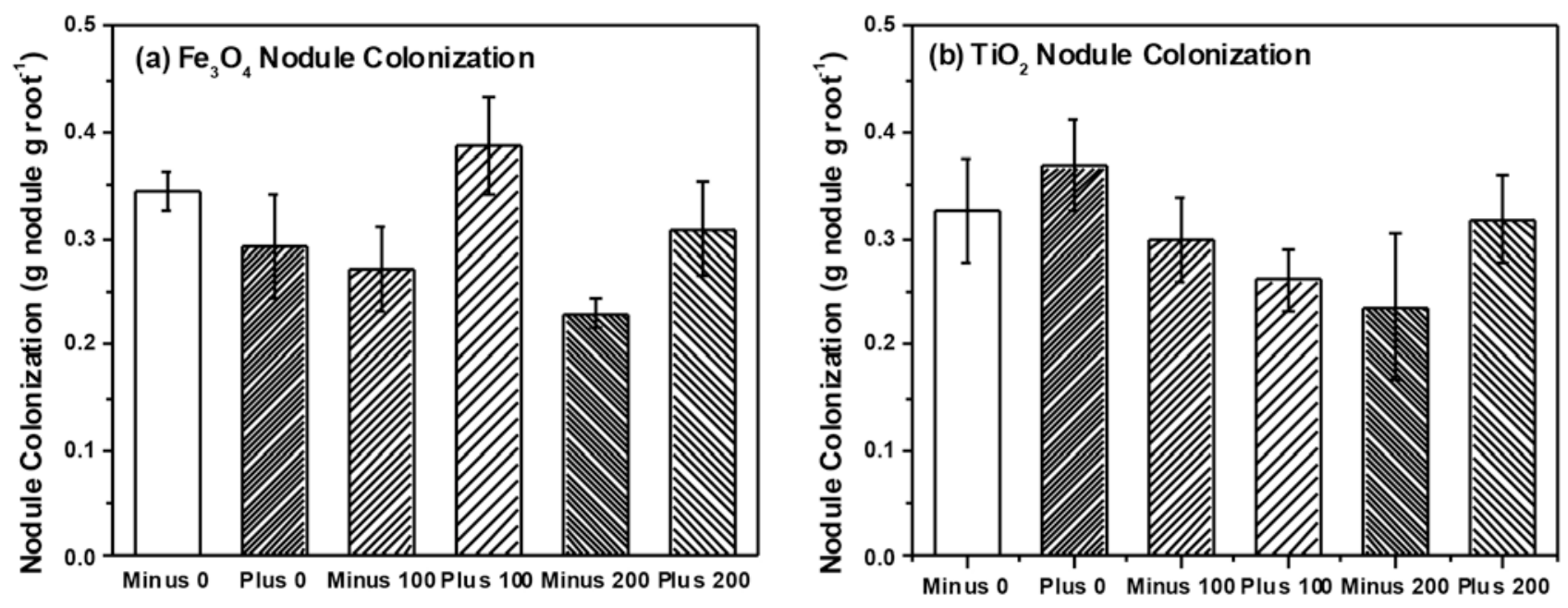

Figure 6. Nodule colonization of soybean plants treated with (a) $\mathrm{Fe}_{3} \mathrm{O}_{4}$ and (b) $\mathrm{TiO}_{2}$, respectively.

\section{Experimental Section}

\subsection{Materials}

The ferroxyhydrate precursor $[\mathrm{FeO}(\mathrm{OH})]$, oleic acid (90\%), 1-octadecene (90\%), trimethylamine (99\%), ammonium hydroxide (14.8 N), ascorbic acid (99\%), ammonium molybdate, sodium arsenite, para-nitrophenol, toluene (HPLC grade 99\%) and ethanol (HPLC grade 90\%) were purchased from Sigma Aldrich (Milwaukee, WI, USA). Trichloroacetic acid, sodium citrate, acetic acid (99\%), sulfuric acid, sodium hydroxide, and P standard were all purchased from Fisher Scientific (Pittsburgh, PA, USA). The silane functionalization agents (3-(triethyoxysilyl)propyl succinic anhydride (95\%) and 3-(2-aminoethylamino)propyl trimethoxysilane (95\%)) were purchased from Gelest (Philadelphia, PA, USA). Commercially available titanium dioxide $\left(\mathrm{TiO}_{2}\right)$ Degussa P25 was purchased from Evonik Industries (Piscataway, NJ, USA). All chemicals and reagents were used as received. 


\subsection{Experimental Set-up and Plant/Soil Sampling}

To examine plant and microbe response to NPs, we studied a widely planted agricultural crop species: Glycine max (L.) Merr. (soybean), under controlled greenhouse conditions. Seeds for soybean (variety Envy) were purchased from Johnny's Selected Seeds (Fairfield, ME, USA). Seeds were planted into 15 cm plastic pots filled with 250 g of sterilized potting soil (Fafard, Agawam, MA, USA; 3B middle weight mix containing 50\% sphagnum peat, processed pine bark, vermiculite, perlite, Dolomitic limestone, and starter nutrients), $200 \mathrm{~g}$ of sterile sand, and $50 \mathrm{~g}$ of air dried field soil for a total of $500 \mathrm{~g}$ of dry soil per pot. The potting soil and sand was sterilized by autoclaving for $40 \mathrm{~min}$ at $121{ }^{\circ} \mathrm{C}$ and was incorporated into the pots after the soil had cooled. Field soil served as a microbial inoculant for our study. The soil used for inoculating the greenhouse pots was collected from a fallow, former agricultural field located at the Holden Arboretum in northeast Ohio. The soil is silt loam topsoil currently occupied by a plant community consisting of non-native grasses and forbs including legumes. The soil $\mathrm{pH}$ at $10 \mathrm{~cm}$ depth was highly acidic with a $\mathrm{pH}$ of approximately 4.0, and the soil total carbon content is between $2 \%-3 \%$ while the soil total nitrogen content is between $0.1 \%-0.2 \%$. Field soil was sieved to remove roots and extraneous material and well mixed before air drying. Field soil was incorporated into the pots containing the well mixed potting soil and sand. After pots were watered, three seeds of soybean were planted into each pot (72 pots total) on 13 January 2015 in a heated greenhouse and well-watered. Supplemental lighting was used and we maintained a 12-h day/night cycle that mimics spring growing conditions. Maximum greenhouse light levels were approximately $150 \mathrm{~W} \cdot \mathrm{m}^{-2}$ under overcast conditions while under bright sky conditions maximum greenhouse light levels were approached $550 \mathrm{~W} \cdot \mathrm{m}^{-2}$. Temperature was maintained between 24 and $29{ }^{\circ} \mathrm{C}$ and seedlings germinated and emerged within 10 days. After emergence, seedlings were thinned to one plant per pot.

On 14 January 2015, one day after planting seeds, we applied NPs to the pots. Treatments were randomly assigned to pots within each row but each treatment was represented within each plant row. In this way bench effects would not affect our results. Plants were rotated across the bench every week during the duration of the study to minimize location effects on plant growth. Pots received either $100 \mathrm{~mL}$ of distilled water and were designated as non-treated controls, or received $100 \mathrm{~mL}$ of distilled water with either 100 or $200 \mathrm{mg}$ of synthesized $\mathrm{Fe}_{3} \mathrm{O}_{4} \mathrm{NP}(-), \mathrm{Fe}_{3} \mathrm{O}_{4} \mathrm{NP}(+), \mathrm{TiO}_{2} \mathrm{P} 25$ (-) and $\mathrm{TiO}_{2} \mathrm{P} 25$ $(+)$. Shallow ( $2 \mathrm{~cm}$ deep) plastic trays were placed under each pot to catch any liquid that drained from the pot and prevent loss of nanoparticle during watering; any water that leaked from the pot was added back to the pot to maintain NP concentrations. Our experimental set-up allowed for a $2 \times 2 \times 3$ factorial design to test for the effect of nanoparticle $\left(\mathrm{Fe}_{3} \mathrm{O}_{4}\right.$ or $\mathrm{TiO}_{2}$-Degussa), charge ( - or + ) or concentration $(0,100$, and $200 \mathrm{mg}$ per $1 \mathrm{~kg}$ of soil) on plant growth and nutrient concentration as well as on microbial community composition within the plant root. Six replicate pots were established for each nanoparticle combination ( 2 NPs $\times 2$ charges $\times 3$ concentrations $\times 6$ replicates $=72$ pots). Plants were arranged on the greenhouse bench, where each row contained one replicate of each plant/nanoparticle treatment combination. Two weeks after seedlings emergence, plants were fertilized with $100 \mathrm{~mL}$ of half strength Peters water soluble general purpose fertilizer (20-20-20) (Scotts Company LLC, Marysville, OH, USA). This was the only supplemental fertilization applied during the study. 
After about 6 weeks of plant growth (8 weeks from sowing), we began to harvest plant biomass and soil from the experimental pots. Since some plants grew faster than others, we harvested plants at the same phenological stage, as they began to set fruit. Plants were thus harvested sequentially, rather than at one time, so that all plants had reached the fruit set stage (R4 stage) and differences in biomass would not reflect differences in individual growth rates of the plants but would reflect treatment conditions. All above- and belowground biomass was collected and separated from the pots. Soil adhering tightly to fine roots (i.e., rhizosphere soil) was gently shaken off, collected and retained. This soil was stored at $-70{ }^{\circ} \mathrm{C}$ and for reserved for future analysis. A coarse mesh sieve (4 mm) was used to separate roots from the remaining soil through gentle washing with tap water. All fine roots recovered in this fashion were used to estimate below ground dry biomass. Root nodules formed by nitrogen-fixing bacteria were removed from roots and separately weighed; nodules were used to estimate colonization of roots by nitrogen fixing bacteria. A small portion of each plant root system was removed, separately weighed and used to estimate mycorrhizal root colonization and community structure.

\subsection{Nanoparticle Synthesis and Characterization}

\subsubsection{Synthesis of Magnetite Nanoparticles $\left(\mathrm{Fe}_{3} \mathrm{O}_{4} \mathrm{NPs}\right)$}

Magnetite NPs were synthesized via a one-step thermal decomposition synthesis approach adopted and modified from the Colvin group [22]. In a typical large scale synthesis, $40 \mathrm{mmol}$ of $\mathrm{FeO}(\mathrm{OH})$ fine powder was stirred with $150 \mathrm{mmol}$ of oleic acid and $75 \mathrm{~mL}$ of 1-octadecene. The mixture was heated up to $320^{\circ} \mathrm{C}$ and kept at reflux for $2 \mathrm{~h}$. The NPs were separated from the reaction mixture via centrifugation after washing with toluene and ethanol. The as-synthesized iron oxide NPs were passivated by oleic acid and showed magnetite crystalline phase (Figure 1).

\subsubsection{Functionalization of $\mathrm{Fe}_{3} \mathrm{O}_{4}$ NPs to Introduce Surface Charges}

The as-synthesized $\mathrm{Fe}_{3} \mathrm{O}_{4}$ NPs ( $1 \mathrm{~g}$ ) were first dissolved in $500 \mathrm{~mL}$ toluene before mixing with $20 \mathrm{~mL}$ of trimethylamine and $200 \mathrm{~mL}$ of $\mathrm{NH}_{4} \mathrm{OH}$ in butanol $(1 \mathrm{M})$. The dispersion was sonicated for 5 min before adding $5 \mathrm{~mL}$ of 3-(triethyoxysilyl)propyl succinic anhydride solution and $10 \mathrm{~mL}$ of water. This was further sonicated for $30 \mathrm{~min}$. The NPs were kept at room temperature for $2 \mathrm{~h}$ until all of the NPs transferred in the water phase. The carboxylic group functionalized $\mathrm{Fe}_{3} \mathrm{O}_{4} \mathrm{NPs}$ were separated through centrifugation and re-dispersed in water [34]. The final $\mathrm{pH}$ was adjusted to $\mathrm{pH} 7$ using dilute acetic acid and triethylamine. For the introduction of amino groups, $1 \mathrm{~g}$ of as-synthesized $\mathrm{Fe}_{3} \mathrm{O}_{4} \mathrm{NPs}$ was first dissolved in $500 \mathrm{~mL}$ toluene before mixing with $20 \mathrm{~mL}$ of trimethylamine. The dispersion was sonicated for $5 \mathrm{~min}$ before adding $5 \mathrm{~mL}$ of 3-(2-aminoethylamino)propyltrimethoxysilane solution. The mixture was stirred at room temperature for $48 \mathrm{~h}$. The particles were then precipitated with petroleum ether and re-dispersed in ethanol. The precipitated particles were washed with ethanol and water a total of three times. The resulting amine functionalized NPs were re-dispersed in water and the $\mathrm{pH}$ was adjusted to 7 to ensure the presence of surface changes for both sample sets. 


\subsubsection{Functionalization of Degussa $\mathrm{TiO}_{2} \mathrm{P} 25$ NPs to Introduce Surface Charges}

Commercially available titanium dioxide $\left(\mathrm{TiO}_{2}\right)$ Degussa P25 (Evonik) was used and modified with amine and carboxylic acid-terminated ligands. Titania samples were dissolved in basic $(\mathrm{pH}=8)$ aqueous solution and 3-(2-aminoethylamino)propyltrimethoxysilane was added and the solution was stirred vigorously and refluxed for $4 \mathrm{~h}$ to obtain amine-terminated titania sample. To obtain carboxylic acid terminated NPs, 3-(triethoxysilyl)propylsuccinic anhydride was used. The solutions were then centrifuged (8500 rpm, $30 \mathrm{~min})$ and washed with water before dispersing in water $(\mathrm{pH}=7)$.

\subsubsection{Characterization}

A Tecnai T12 transmission electron microscope (TEM) operated at $80 \mathrm{kV}$ was used to evaluate the size and morphology of the NPs. The software ImageJ was used to measure the particle size of an average of 200 particles to estimate the size distribution for each sample. The powder X-ray diffraction (PXRD) patterns of the samples were collected using a RigakuMiniFlex X-ray powder diffractometer using $\mathrm{Cu} \mathrm{K \alpha}$ radiation $(\gamma=0.154 \mathrm{~nm}$ ). The surface functionalization of the NPs were evaluated using attenuated total reflectance-Fourier transform infrared spectroscopy (ATR-FTIR) conducted in the range $600-4000 \mathrm{~cm}^{-1}$ using a Thermo Scientific Nexus 870 ATR-FTIR spectrometer. The particle size distributions were analyzed using dynamic light scattering (DLS) on a ZetaPALS particle size analyzer (Brookhaven, Upton, NY, USA) at a scattering angle of $90^{\circ}$. The elemental analyses were conducted using atomic absorption spectroscopy (AAS). UV-Visible absorption measurements were carried out using a CARY 50 BIO spectrophotometer. Standard solutions of 0, 0.1, 0.4, 1.0 and 2.0 ppm were prepared from a 10 ppm P standard stock solution. Calibration curves were generated using standards. Absorbance measurements were read using the peak at $700 \mathrm{~nm}$.

\subsection{Plant Growth and Elemental Analysis}

Aboveground and belowground biomass harvested from the pots was dried at $60{ }^{\circ} \mathrm{C}$ for one week, and weighed. Once dry, all plant tissue, except for that portion of the root system reserved for DNA extraction, was finely ground in a tissue grinder to reduce particle size, and then pulverized in a Precellys homogenizer (Bertin Technologies, Montigny-le-Bretonneux, France) to produce a fine powder suitable for analysis of $\mathrm{C}$ and $\mathrm{N}$. The total plant $\mathrm{C}$ and $\mathrm{N}$ were analyzed by a dry combustion method on an ECS 4010 CHNSO elemental analyzer (Costech Analytical, Valencia, CA, USA). Total leaf and root $\mathrm{P}$ was determined through acid digestion using sulfuric acid and $30 \%$ hydrogen peroxide [35] followed by colorimetric analysis using the modified ascorbic acid method [36]. All sample aliquots were adjusted to $\mathrm{pH} 8$ before analysis. For total leaf and root $\mathrm{Fe}$ and $\mathrm{Ti}$, samples were acid-digested at $150{ }^{\circ} \mathrm{C}$ for $4 \mathrm{~h}$ in pressurized Teflon lined vessels with $70 \%$ nitric acid. Samples were diluted to a final concentration of $3 \%$ nitric acid and analyzed for Fe using flame AAS. Samples were diluted to a final concentration of $2 \%$ nitric acid and analyzed for Ti using graphite furnace atomic absorption spectroscopy (GFAAS). A blank sample was run in between measurements to clean the pyrolytic graphite tube and eliminate Ti memory effects. The iron (Fe) standard solutions $(0,0.5,1,2$, 4, 8 ppm) were prepared from a $1000 \mathrm{ppm}$ in 3\% $\mathrm{HNO}_{3} \mathrm{Fe}$ stock solution (Ricca Chemical Co., Batesville, IN, USA). On the other hand, the titanium (Ti) standard solutions (0, 10, 20, 30, $40 \mathrm{ppb}$ ) were 
prepared from a $1000 \mathrm{ppm}$ in $2 \% \mathrm{HNO}_{3} \mathrm{Ti}$ stock solution (Fluka Analytical, Sigma-Aldrich Co., St. Louis, MO, USA).

\subsection{Analysis of Microbial Communities}

DNA was extracted from wet roots using a bead beating protocol [37]. In short, 100-500 mg of roots were placed in a $1.5 \mathrm{~mL}$ bead beating tube containing $500 \mathrm{mg}$ of sterile glass beads (300 mg of $400 \mu \mathrm{M}$ glass beads (VWR, West Chester, PA, USA), $200 \mathrm{mg}$ of $1 \mathrm{~mm}$ glass beads (Chemglass, Vineland, NJ, USA) ) and $750 \mu \mathrm{L}$ of $2 \%$ CTAB (cetyltrimethylammonium bromide). Samples were beaten for $90 \mathrm{~s}$ in a Precellys homogenizer at $6500 \mathrm{rpm}$. Approximately $500 \mathrm{~mL}$ of the supernatant was removed and purified by phenol/chloroform extraction and precipitation with $20 \%$ polyethylene glycol 8000 in $2.5 \mathrm{M}$ $\mathrm{NaCl}$ [37]. DNA was suspended in $50 \mu \mathrm{L}$ TE (Tris EDTA) buffer and stored at $-20{ }^{\circ} \mathrm{C}$ until use.

For analysis of arbuscular mycorrhizal (AM) fungi, we targeted the 18S rRNA gene using AM specific primer AM1 [38] and general eukaryotic primer NS31 [39]. The PCR was conducted in $50 \mu \mathrm{L}$ reaction volumes containing $1 \mu \mathrm{L}$ of purified DNA (approximately $100 \mathrm{ng}$ ), $0.2 \mu \mathrm{M}$ of each primer, $2.0 \mathrm{mM} \mathrm{MgCl}, 0.2 \mathrm{mM}$ dNTP, $0.15 \mathrm{mg} \cdot \mathrm{mL}^{-1}$ bovine serum albumin, and 2.0 units GoTaq DNA polymerase (Promega Corporation, Madison, WI, USA). The PCR was carried out on a PTC 100 Thermal Cycler (MJ Research, Boston, MA, USA) using cycling conditions in Helgason et al. except that 32 cycles were used for PCR and the annealing temperature was $60{ }^{\circ} \mathrm{C}$ [38]. The primer NS31 was labeled with the fluorochrome HEX (4,7,2',4',5',7'-hexachloro-6-carboxyfluorescein) and PCR product was used for analysis of AM fungal communities using terminal restriction fragment length polymorphism procedures [40]. PCR product was digested with the restriction enzyme HinfI (Promega, Madison, WI, USA) and TRFLPs were completed through the Cornell Bioresource Center using an Applied BioSystems 3730xl DNA Analyzer and the GS600 LIZ size standard. Profiles were analyzed using Peak Scanner ${ }^{\mathrm{TM}}$ Software (version 1.0, Applied Biosystems 2006, Foster City, CA, USA) and only peaks that accounted for greater than $1 \%$ of the relative peak area were included in this analysis (i.e., major TRFs) [41]. To estimate root length colonized by AM fungi, we used quantitative PCR (qPCR) using primer AM1 and primer AM1GF, which generates an approximately 210 base pair long amplicons [40]. The qPCR was conducted in $20 \mu \mathrm{L}$ reaction volumes using $1 \times$ iTaqUniversal ${ }^{\mathrm{TM}} \mathrm{SYBR}^{\circledR}$ Green Supermix (Bio-Rad) on a MiniOpticon ${ }^{\mathrm{TM}}$ real-time PCR detection system (Bio-Rad Laboratories, Inc., Hercules, CA, USA) following procedures developed by Hewins et al. [40]. Colonization is reported as copy number per gram of dry root tissue.

For analysis of nitrogen-fixing bacteria, we extracted DNA from root nodules using a modification of the procedure described above. In short, we bead beat nodules for $90 \mathrm{~s}$, then ground the nodules within the tube with a sterile micro-pestle, before bead beating the nodules again for $45 \mathrm{~s}$. Samples were purified by phenol-chloroform extraction and suspended in $100 \mu \mathrm{L}$ TE buffer. To examine effects on nitrogenfixing bacteria in root nodules, we targeted nifH, the structural gene for the enzyme nitrogenase reductase, using primers and conditions following Widmer et al. [42] Primer nifH (for Rev) was labeled with the fluorochrome HEX and used with primer nifH (for A). This generated an approximately 450 base pair PCR product that was used for TRFLP analysis using the procedure described above but using HaeIII (Promega, Madison, WI, USA) as the restriction enzyme.

3.6. Data and Statistical Analysis 
Differences in biomass, plant nutrient and metal content, and colonization by AM fungi and rhizobia were analyzed by 3-way ANOVA using procedures in SigmaStat 3.5 (Systat Software Inc., San Jose, CA, USA). The Kolmogorov-Smirnov test was used to determine if data were normally distributed prior to analysis. To examine uptake of metals (i.e., Fe or Ti) we used 3-way ANOVA to determine effects of plant tissue, metal concentration and charge on metal distribution in plant tissue. Analysis was conducted on transformed (log 10) data for Fe in order for data to meet normality assumptions; Ti data met normality assumptions and analysis was conducted on untransformed data. Since 3-way ANOVA showed differences in how plants responded to metal type (i.e., $\mathrm{Fe}$ or $\mathrm{Ti}$ ), we also conducted 2-way ANOVA on dry biomass data to explore within metal treatment responses. Nutrient data for $\mathrm{C}$ and $\mathrm{N}$ were $\log 10$ transformed to meet normality assumptions but $\mathrm{P}$ data met normality assumptions and data were analyzed untransformed. Pairwise multiple comparison procedures (Holm-Sidak Method) were used to determine which means were different when significant contrasts were found with ANOVA.

TRFLP profiles were used to examine the effects of nanoparticle treatment on AM fungal and rhizobia nodule communities. Detected TRFs were used as operational taxonomic units (OTU) and are treated as microbial taxa for these analyses even though each TRF may represent many microbial species [43-45]. The relative peak area was used for each TRF as a measure of relative abundance within the community, and peak area data were used for non-metric multidimensional scaling (NMS) analysis of community structure using PC-ORD 4 (MjM Software, Gleneden Beach, OR, USA). The Sørenson distance with a random starting configuration was used for these analyses. A maximum of 400 iterations were used for 50 runs, with data for the Monte Carlo test randomized. PC-ORD was run in autopilot mode and dimensionality confirmed manually. The best dimensionality for the order was chosen when additional dimensions did not reduce the stress by more than 5 . We also used multi-response permutation procedures (MRPP), a nonparametric, multivariate procedure for testing the hypothesis of no difference between groups [46], to further confirm effects of plant and nanoparticle treatment on microbial communities. For MRPP, the Sørenson distance was used for all analyses.

\section{Conclusions}

Our examination of the effects of $\mathrm{Fe}_{3} \mathrm{O}_{4}$ and $\mathrm{TiO}_{2}$ NPs on soybean roots found that these NPs had differing effect on plant growth, nutrient content and root microbes, and that the charge of the NP played an important role in these differences. Although $\mathrm{Fe}_{3} \mathrm{O}_{4} \mathrm{NPs}$ increased plant growth and leaf $\mathrm{C}$ content as compared to $\mathrm{TiO}_{2} \mathrm{NPs}$, leaf $\mathrm{P}$ levels were reduced. Moreover, negatively charged $\mathrm{Fe}_{3} \mathrm{O}_{4} \mathrm{NPs}$ increased leaf $\mathrm{P}$ content, the translocation of Fe to leaf tissue, and decreased root colonization of rhizobia relative to positively charged $\mathrm{Fe}_{3} \mathrm{O}_{4}$ NPs. Although the causes of these differences with NP charge are unclear, our study suggests that plant and microbial responses to NP will be context dependent and determined by the identity of the NP, its charge and concentration. 


\section{Acknowledgments}

This work was supported by funding from the Holden Arboretum Trust, the Corning Institute for Education and Research (David J. Burke) and by an NSF-CAREER Grant (DMR-1253358) from the Solid State and Materials Chemistry Program (Anna Cristina S. Samia). The authors thank Charlotte Hewins for assistance with plant nutrient analysis and Sarah Carrino-Kyker for assistance with qPCR. We also acknowledge the assistance of Jim Faulk in the Ti and Fe AAS analysis.

\section{Author Contributions}

Anna Cristina S. Samia and David J. Burke designed the experiments and wrote the paper; Shu F. Situ and Eric C. Abenojar synthesized, performed surface functionalization, and characterized the $\mathrm{Fe}_{3} \mathrm{O}_{4}$ and $\mathrm{TiO}_{2}$ NPs, respectively; Mya Porche, Pawel Kraj, and Yutthana Lakliang conducted the P analysis; Shu F. Situ and Eric C. Abenojar conducted the Ti and Fe analysis; David J. Burke and Nicole Pietrasiak measured plant biomass; and Nicole Pietrasiak performed molecular characterization of microbial communities and qPCR for colonization of AM fungi.

\section{Conflicts of Interest}

The authors declare no conflict of interest.

\section{References}

1. Ma, X.; Geisler-Lee, J.; Deng, Y.; Kolmakov, A. Interactions between engineered nanoparticles (ENPs) and plants: Phytotoxicity, uptake and accumulation. Sci. Total Environ. 2010, 408, 3053-3061.

2. Benn, T.M.; Westerhoff, P. Nanoparticle silver released into water from commercially available sock fabrics. Environ. Sci. Technol. 2008, 42, 4133-4139.

3. Klaine, S.J.; Alvarez, P.J.J.; Batley, G.E.; Fernandes, T.F.; Handy, R.D.; Lyon, D.Y.; Mahendra, S.; McLaughlin, M.J.; Lead, J.R. Nanomaterials in the environment: Behavior, fate, bioavailability, and effects. Environ. Toxicol. Chem. 2008, 27, 1825.

4. Sobha, K.; Surendranath, K.; Meena, V.; Jwala, T.K.; Swetha, N.; Latha, K.S.M. Emerging trends in nanobiotechnology. In Biotechnology and Molecular Biology Reviews; Academic Journals: Nairobi, Kenya, 2010; Volume 4, pp. 1-12.

5. Rai, M.; Ingle, A. Role of nanotechnology in agriculture with special reference to management of insect pests. Appl. Microbiol. Biotechnol. 2012, 94, 287-293.

6. Throbäck, I.N.; Johansson, M.; Rosenquist, M.; Pell, M.; Hansson, M.; Hallin, S. Silver $\left(\mathrm{Ag}^{+}\right)$reduces denitrification and induces enrichment of novel nirk genotypes in soil. FEMS Microbiol. Lett. 2007, 270, 189-194.

7. Priester, J.H.; Ge, Y.; Mielke, R.E.; Horst, A.M.; Moritz, S.C.; Espinosa, K.; Gelb, J.; Walker, S.L.; Nisbet, R.M.; An, Y.-J.; et al. Soybean susceptibility to manufactured nanomaterials with evidence for food quality and soil fertility interruption. Proc. Natl. Acad. Sci. USA 2012, 109, E2451-E2456. 
8. Ghosh, M.; Bandyopadhyay, M.; Mukherjee, A. Genotoxicity of titanium dioxide $\left(\mathrm{TiO}_{2}\right)$ nanoparticles at two trophic levels: Plant and human lymphocytes. Chemosphere 2010, 81, 1253-1262.

9. Asli, S.; Neumann, P.M. Colloidal suspensions of clay or titanium dioxide nanoparticles can inhibit leaf growth and transpiration via physical effects on root water transport. Plant Cell Environ. 2009, 32, 577-584.

10. Ge, Y.; Schimel, J.P.; Holden, P.A. Identification of soil bacteria susceptible to $\mathrm{TiO}_{2}$ and $\mathrm{ZnO}$ nanoparticles. Appl. Environ. Microb. 2012, 78, 6749-6758.

11. Burke, D.J.; Zhu, S.; Pablico-Lansigan, M.P.; Hewins, C.R.; Samia, A.C.S. Titanium oxide nanoparticle effects on composition of soil microbial communities and plant performance. Biol. Fertil. Soils 2014, 50, 1169-1173.

12. Boonyanitipong, P.K.B.; Kumar, P.; Baruah, S.; Dutta, J. Toxicity of $\mathrm{ZnO}$ and $\mathrm{TiO}_{2}$ nanoparticles on germinating rice seed oryza sativa L. Int. J. Biosci. Biochem. Bioinform. 2011, 1, 282-285.

13. Kim, E.; Kim, S.-H.; Kim, H.-C.; Lee, S.G.; Lee, S.J.; Jeong, S.W. Growth inhibition of aquatic plant caused by silver and titanium oxide nanoparticles. ToxEHS 2011, 3, 1-6.

14. Lin, D.; Xing, B. Phytotoxicity of nanoparticles: Inhibition of seed germination and root growth. Environ. Pollut. 2007, 150, 243-250.

15. Yoon, S.J.; Kwak, J.I.; Lee, W.M.; Holden, P.A.; An, Y.J. Zinc oxide nanoparticles delay soybean development: A standard soil microcosm study. Ecotoxicol. Environ. Saf. 2014, 100, 131-137.

16. Ge, Y.; Priester, J.H.; van de Werfhorst, L.C.; Walker, S.L.; Nisbet, R.M.; An, Y.J.; Schimel, J.P.; Gardea-Torresdey, J.L.; Holden, P.A. Soybean plants modify metal oxide nanoparticle effects on soil bacterial communities. Environ. Sci. Technol. 2014, 48, 13489-13496.

17. Rico, C.M.; Majumdar, S.; Duarte-Gardea, M.; Peralta-Videa, J.R.; Gardea-Torresdey, J.L. Interaction of nanoparticles with edible plants and their possible implications in the food chain. J. Agric. Food Chem. 2011, 59, 3485-3498.

18. Arruda, S.C.C.; Silva, A.L.D.; Galazzi, R.M.; Azevedo, R.A.; Arruda, M.A.Z. Nanoparticles applied to plant science: A review. Talanta 2015, 131, 693-705.

19. Hodge, A.; Campbell, C.D.; Fitter, A.H. An arbuscular mycorrhizal fungus accelerates decomposition and acquires nitrogen directly from organic material. Nature 2001, 413, 297-299.

20. Emami-Karvani, Z.; Chehrazi, P. Antibacterial activity of ZnO nanoparticle on gram-positive and gram-negative bacteria. Afr. J. Microbiol. Res. 2011, 5, 1368-1373.

21. Murata, T.; Kanao-Koshikawa, M.; Takamatsu, T. Effects of Pb, Cu, Sb, In and Ag contamination on the proliferation of soil bacterial colonies, soil dehydrogenase activity, and phospholipid fatty acid profiles of soil microbial communities. Water Air Soil Pollut. 2005, 164, 103-118.

22. Yu, W.W.; Falkner, J.C.; Yavuz, C.T.; Colvin, V.L. Synthesis of monodisperse iron oxide nanocrystals by thermal decomposition of iron carboxylate salts. Chem. Commun. 2004, 2306-2307.

23. Hernandez-Viezcas, J.A.; Castillo-Michel, H.; Andrews, J.C.; Cotte, M.; Rico, C.; Peralta-Videa, J.R.; Ge, Y.; Priester, J.H.; Holden, P.A.; Gardea-Torresdey, J.L. In situ synchrotron $\mathrm{X}$-ray fluorescence mapping and speciation of $\mathrm{CeO}_{2}$ and $\mathrm{ZnO}$ nanoparticles in soil cultivated soybean (Glycine max). ACS Nano 2013, 7, 1415-1423. 
24. Garcia-Gomez, C.; Babin, M.; Obrador, A.; Alvarez, J.M.; Fernandez, M.D. Integrating ecotoxicity and chemical approaches to compare the effects of $\mathrm{ZnO}$ nanoparticles, $\mathrm{ZnO}$ bulk, and $\mathrm{ZnCl}_{2}$ on plants and microorganisms in a natural soil. Environ. Sci. Pollut. Res. 2015, doi:10.1007/s11356-015-4867-y.

25. Hong, F.; Zhou, J.; Liu, C.; Yang, F.; Wu, C.; Zheng, L.; Yang, P. Effect of nano-TiO2 on photochemical reaction of chloroplasts of spinach. Biol. Trace Elem. Res. 2005, 105, 269-279.

26. Lu, C.; Zhang, C.; Wen, J.; Wu, G.; Tao, M. Research of the effect of nanometer materials on germination and growth enhancement of Glycine max and its mechanism. Soybean Sci. 2002, 21, 168-171.

27. Gao, F.; Hong, F.; Liu, C.; Zheng, L.; Su, M.; Wu, X.; Yang, F.; Wu, C.; Yang, P. Mechanism of nano-anatase $\mathrm{TiO}_{2}$ on promoting photosynthetic carbon reaction of spinach: Inducing complex of rubisco-rubisco activase. Biol. Trace Elem. Res. 2006, 111, 239-253.

28. Yang, F.; Liu, C.; Gao, F.; Su, M.; Wu, X.; Zheng, L.; Hong, F.; Yang, P. The improvement of spinach growth by nano-anatase $\mathrm{TiO}_{2}$ treatment is related to nitrogen photoreduction. Biol. Trace Elem. Res. 2007, 119, 77-88.

29. English, J.E.; Maynard, D.N. A key to nutrient disorders of vegetable plants. HortScience 1977, 13, 28-29.

30. Schlesinger, W.H. Biogeochemistry: An Analysis of Global Change, 2nd ed.; Academic Press: San Diego, CA, USA, 1997; p. 588.

31. Farago, M.E. Plants and The Chemical Elements: Biochemistry, Uptake, Tolerance, and Toxicity; Wiley-VCH Verlag GmbH: Weinheim, Germany, 1994.

32. Harris, A.T.; Bali, R. On the formation and extent of uptake of silver nanoparticles by live plants. J. Nanopart. Res. 2008, 10, 691-695.

33. Brear, E.M.; Day, D.A.; Smith, P.M.C. Iron: An essential micronutrient for the legume-rhizobiumsymbiosis. Front. Plant Sci. 2013, 4, 359.

34. Feng, Z.; Zhu, S.; Martins de Godoi, D.R.; Samia, A.C.S.; Scherson, D. Adsorption of $\mathrm{Cd}^{2+}$ on carboxyl-terminated superparamagnetic iron oxide nanoparticles. Anal. Chem. 2012, 84, 3764-3770.

35. Moore, K. Determination of phosphorus in plant tissue by colorimetry. In Plant Analysis Reference Procedures for the Southern Region of the United States; Plank, C., Ed.; Georgia Agricultural Experiment Station: Athens, GA, USA, 1992.

36. Kuo, S. Phosphorus. In Methods of Soil Analysis. Part 3, Chemical Methods; Sparks, D., Ed.; American Society of Agronomy-Soil Science Society of America: Madison, WI, USA, 1996; pp. 869-919.

37. Burke, D.J.; Kretzer, A.M.; Rygiewicz, P.T.; Topa, M.A. Soil bacterial diversity in a loblolly pine plantation: Influence of ectomycorrhizas and fertilization. FEMS Microbiol. Ecol. 2006, 57, 409-419.

38. Helgason, T.; Daniell, T.J.; Husband, R.; Fitter, A.H.; Young, J.P. Ploughing up the wood-wide web? Nature 1998, 394, 431.

39. Simon, L.; Lalonde, M.; Bruns, T.D. Specific amplification of 18s fungal ribosomal genes from vesicular-arbuscular endomycorrhizal fungi colonizing roots. Appl. Environ. Microb. 1992, 58, 291-295. 
40. Hewins, C.R.; Carrino-Kyker, S.R.; Burke, D.J. Seasonal variation in mycorrhizal fungi colonizing roots of Allium tricoccum (wild leek) in a mature mixed hardwood forest. Mycorrhiza 2015, 25, 469-483.

41. Burke, D.J. Effects of Alliaria petiolata (garlic mustard; Brassicaceae) on mycorrhizal colonization and community structure in three herbaceous plants in a mixed deciduous forest. Am. J. Bot. 2008, 95, 1416-1425.

42. Widmer, F.; Shaffer, B.T.; Porteous, L.A.; Seidler, R.J. Analysis of nifh gene pool complexity in soil and litter at a douglas fir forest site in the oregon cascade mountain range. Appl. Environ. Microb. 1999, 65, 374-380.

43. Burke, D.J.; Chan, C.R. Effects of the invasive plant garlic mustard (Alliaria petiolata) on bacterial communities in a northern hardwood forest soil. Can. J. Microbiol. 2010, 56, 81-86.

44. Burke, D.J.; Dunham, S.M.; Kretzer, A.M. Molecular analysis of bacterial communities associated with the roots of douglas fir (Pseudotsuga menziesii) colonized by different ectomycorrhizal fungi. FEMS Microbiol. Ecol. 2008, 65, 299-309.

45. Feinstein, L.M.; Sul, W.J.; Blackwood, C.B. Assessment of bias associated with incomplete extraction of microbial DNA from soil. Appl. Environ. Microb. 2009, 75, 5428-5433.

46. McCune, B.; Grace, J.B. Analysis of Ecological Communities Book; Mjm Software Design: Gleneden Beach, OR, USA, 2002.

(C) 2015 by the authors; licensee MDPI, Basel, Switzerland. This article is an open access article distributed under the terms and conditions of the Creative Commons Attribution license (http://creativecommons.org/licenses/by/4.0/). 